The Journal of Public Space

2016 | Vol. I, n. I

\title{
VIEWPOINT
}

\section{This is My City}

\section{Leonardo Parra-Agudelo}

Queensland University of Technology, Australia

Creative Industries Faculty, School of Design, Urban Informatics Research Lab I.parraagudelo@qut.edu.au | @Parra_Leonardo

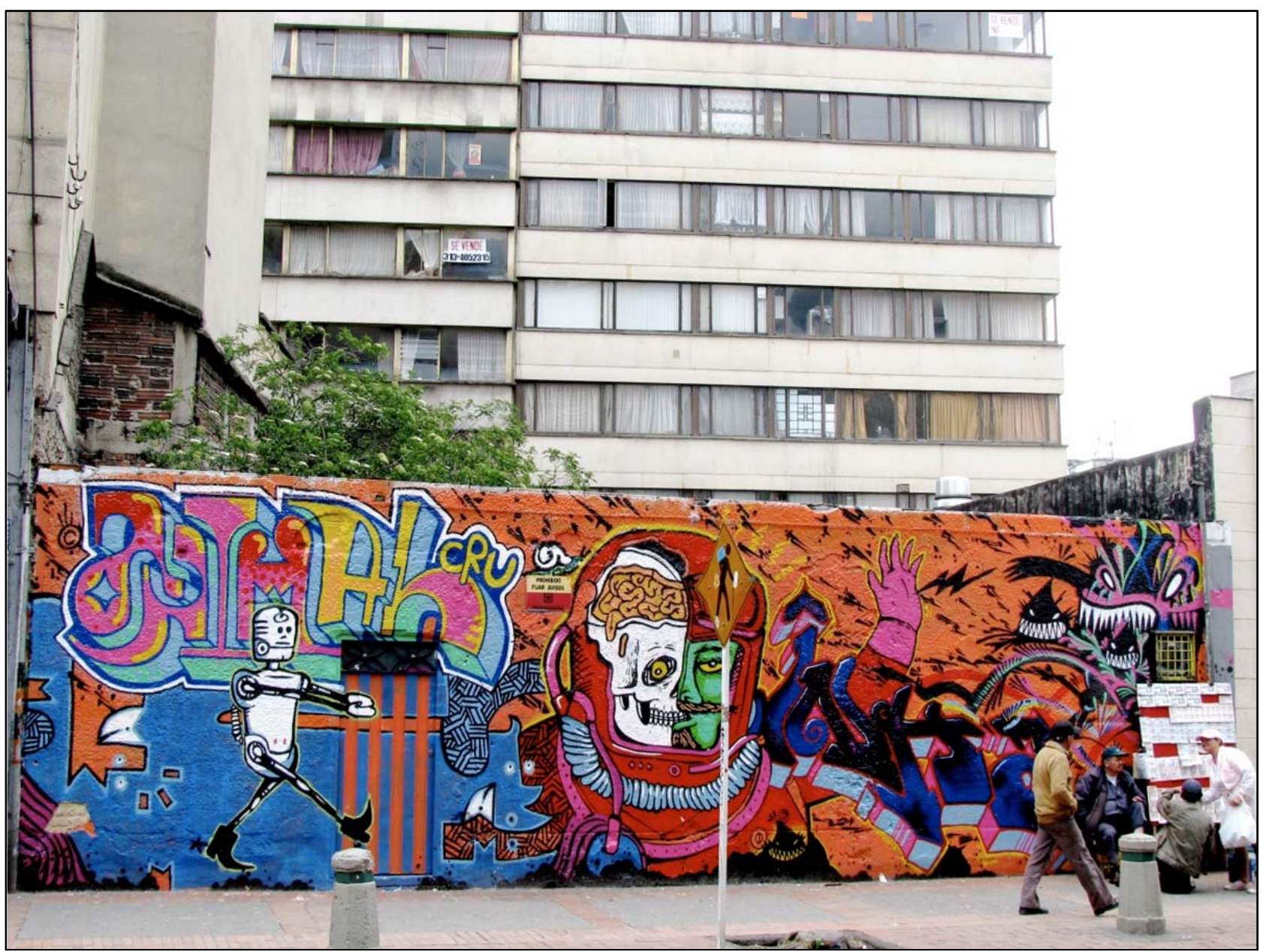

Wall painted in the context of the Scoundrel Memory Exhibition, Museo de Bogota by Buytronick, Chirrete, Mecamutanterio, Zas-Inha, Stinkfish, Juan Canales \& Jungla. Bogota, Colombia.

I would like to think l'm a good person. I've studied how to transform things with my hands, with projects, with words, with education. I was initially trained to solve problems by bringing new artefacts to existence; my training makes me shiver with distrust now. I walk with equal fascination through nature and urban environments and the clash 
between the two upsets me greatly. The depth and breadth of the human endeavour fascinates me and I'm saddened I will never have access to it all. Through my work I have embraced the good and the bad, in an attempt to understand myself and others. Conflict is at the core of what I do and sometimes I materialise it in ways that are not appreciated by others. A few years ago someone I regard highly said that I was interested in everything under the sun; it cannot be any other way.

I hold a bachelor's degree in industrial design from Universidad de los Andes (Colombia) and an M.F.A. in Design \& Technology from Parsons School of Design (US). I'm currently based in the Urban Informatics Research Lab, Queensland University of Technology (Australia) and I expect to finish a PhD in design for social change with a focus on South American cities this year.

For this issue, I was asked to provide a viewpoint on the experience of public space as someone that has been involved in graffiti and street art for more than ten years. My involvement with these two forms of street interventions, that for outsiders co-exist and for insiders collide, is mostly situated in Bogota, Colombia. The living conditions of the inhabitants of the capital city of a country embedded in more than fifty years of internal violence were, and still are, precarious for many but not so much for me. I was raised in a middle class home and was well taken care of.
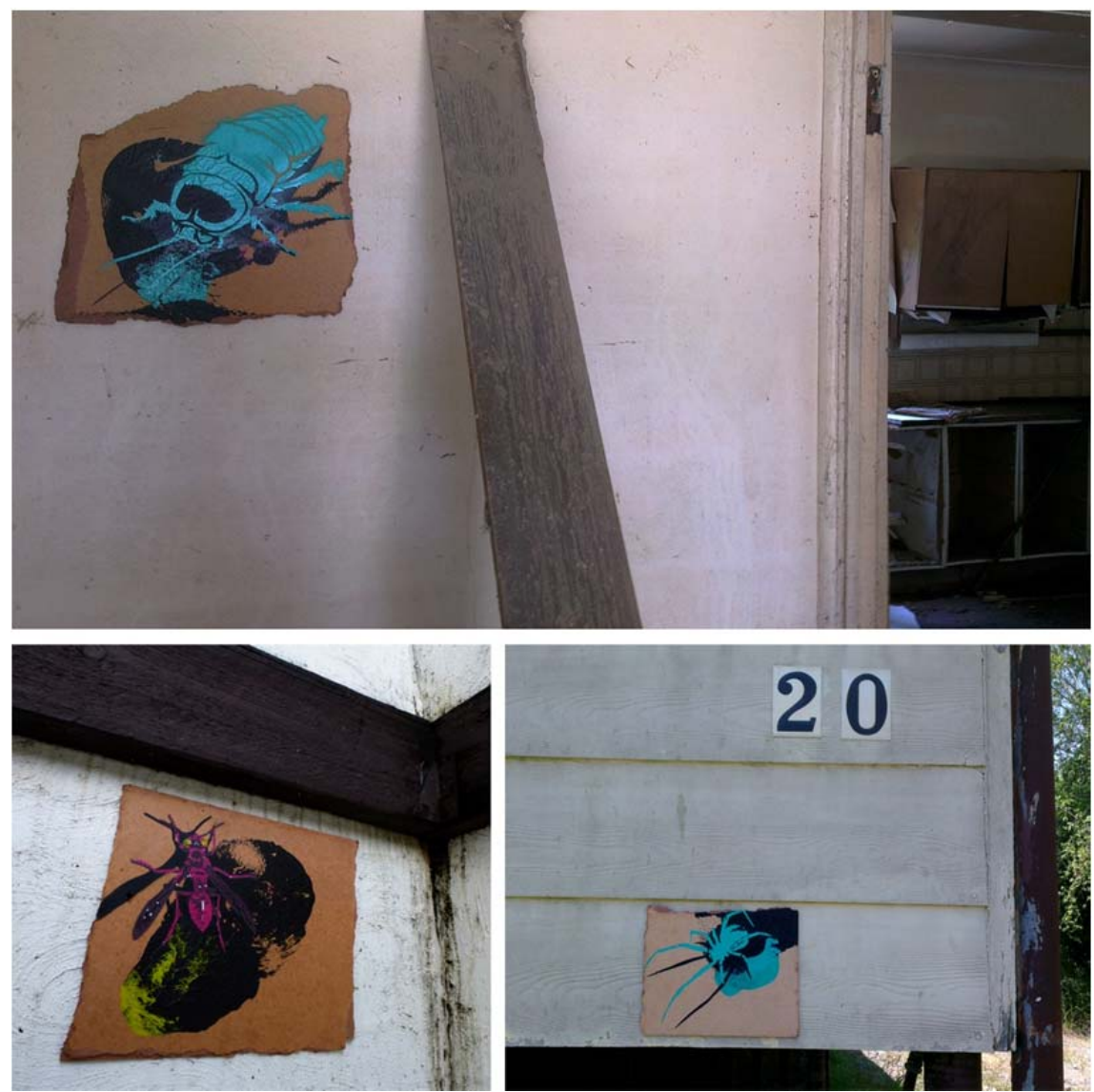

Upper picture: roaming around outer city suburbs like the two-layer Australian cockroach stencil. Bottom left: seven-layer wasp on discarded wooden board flies around an inner-city suburb. Bottom right: two-layer Red Back spider stencil in an abandoned house. 
Throughout my childhood I lived in gated communities and the entrapment in the city was palpable; we could not go anywhere. Gated communities were all I had. The city, the countryside, the country did not belong to me, I was there, but it was all borrowed from someone that could get rid of me without anyone knowing where I had gone. These things were beyond my reach and I complied. What I knew about the city were the things my parents knew were safe for me. I grew up protected and sheltered. I adapted to the situation, and then skateboarding appeared in my life. I had my own wheels, I could go places. I was chased by guards out of shopping malls and my understanding of the city changed. Where other people saw staircases I saw heel flips and tail grabs. I started to read public space as a playground, a nose slide here and a grind there. It was really fantastic. I developed a navigating sense based on the sites where tricks could be executed.
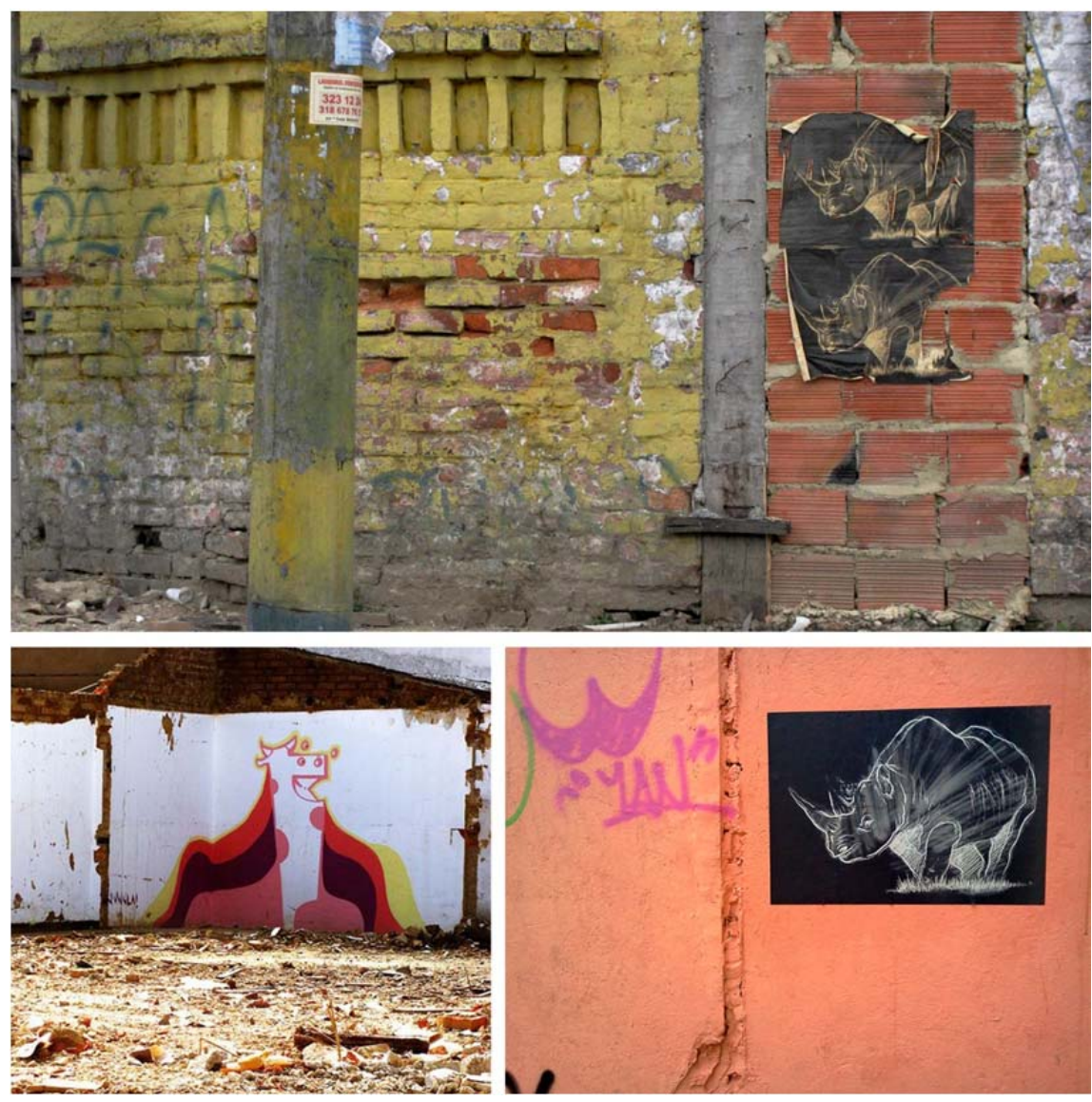

Upper picture: rhinoceros decaying as the building they're on. Bottom left: strength in numbers: 1000 rhinoceros were printed in newspaper paper. 200 have seen the city so far. Bottom right: Melting cow in a derelict area of northern Bogota.

Years later, after a two year absence, I returned to see Bogota covered in spray paint. I could not miss the opportunity to contribute; I had discovered my new skateboarding. I no longer needed wheels; I just needed a pair of cans of spray paint and a sketchbook. To this day I keep a record of the walls that need some colour. Perhaps I need to see colours 
in them; it really doesn't matter, I had the tools to take over of what was taken away from me when I was a kid. The chance to make my voice publicly heard had come and I was going to embrace it with a pair of runners, a black hoodie and a pink dot fat cap on my cans. I started my late night outings painting a set of smiling animals: cats, cows, bulls, rhinos, etc. I wanted to give back to the city that had given me so much after all, I had grown up there-, to its people, I wanted to tell them, and tell myself, that not everything was bad. I wanted to say that I was there to share happy thoughts. At the time I didn't know about old school bomber Pez from Barcelona and his happy schools of fish. Much has changed since early 2006 when I got interested in exploring my own voice through spray paint and homemade glue. The country is in much better shape now and the current peace agreements promise an enormous change, however, inequality and discrimination are still ubiquitous throughout and the transformation required calls for a lot of hard work. As an individual citizen, I saw public spaces as the platform from which to contribute to that transformation, even if that meant shattering the old through contested means. I still see public spaces this way, I still paint -and the country still makes me cry- and I own the spots where l've painted. The message is out there, even if only for a few days: this is my city, it belongs to you too, it's time to change it and what you see here is my colourful contribution towards that new Bogota.

\section{To cite this article:}

Parra-Agudelo, L. (20I6). This is My City. The Journal of Public Space, I(I), I47-I50, DOI: 10.5204/jps.vlil.16

This article has been accepted for publication in The Journal of Public Space. Please see the Editorial Policies under the 'About' section of the journal website for further information.

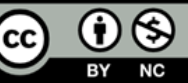

This work is licensed under a Creative Commons Attribution - Non Commercial 4.0 International License. https://creativecommons.org/licenses/by-nc/4.0/ 